\title{
Developing Crisis Management Skills Through A Realistic Case Scenario
}

Connie B. Budden, Southeastern Louisiana University, USA

Michael C. Budden, Southeastern Louisiana University, USA

\begin{abstract}
Increasingly, managers and public relations officials seem to be at the forefront of newscasts as a variety of organizational crises develop. Business educators attempting to teach appropriate crises management knowledge and develop skills needed to address such a crises should incorporate realistic case scenarios to challenge students. Such realistic cases should appropriately address communication and management needs related to crises that may develop. This paper presents a realistic case that has been used to instill crisis management skills in a business public relations class.
\end{abstract}

Keywords: Case scenario; crisis management; planning; public relations

\section{INTRODUCTION}

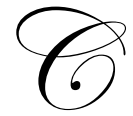

ase analyses are widely used in management education. In fact, it would be a rare, if not a unique, educational program that did not incorporate some case analyses into management and public relations education. Years ago, crises such as the Watergate Affair, the tainted Tylenol scare, and the serious nuclear reactor problem at Three Mile Island, served to alert those in public relations and management positions that a well-prepared crisis management plan that was faithfully executed was central to good management practices.

More recent newsworthy crises have occurred, including the unprecedented recall of Toyotas for sudden acceleration, the recall of 500 million eggs, government interventions into General Motors and Chrysler, the plethora of troubled banks and other organizations arising from the sub-prime loan crisis, Hurricane Katrina's aftermath, the Deepwater Horizon catastrophe and resulting BP Oil spill in the Gulf of Mexico, suicides of students, binge drinking deaths on college campuses, shootings in schools and other crises presented many with opportunities to exercise and test crisis management plans. Arguably, the manner in which these crises were dealt with resulted in varying degrees of success. Indeed, some managers and their firms might be described as having been successful in dealing with crises while others have failed.

As Arens (2006) and Arens and Schaefer (2007) explain, one of the more important public relations tasks for a corporation is to plan and address the need for crisis management adequately. Lamb, Hair and McDaniel (2006) believe that companies must have a communications policy in hand before a crisis occurs. Seitel (2007) proffers that the manner in which a crisis is handled may influence for years how consumers perceive an organization. Indeed, Seitel mentions that when it comes to potential crises, a sense of heightened preparedness is needed and that managers should act appropriately, be prepared, available and credible.

In dealing with crises, a plan of action is preferred. While plans for dealing with crises may have similar components, it is likely the specifics of different plans will vary. Indeed, some would argue that a one-size-fits all policy leaves room for criticism (Hill, 2011: p. 363). Regardless, there is a need for organizational leaders to demonstrate that they possess the skills and competence to deal with crises (Lussier \& Achua, 2007: p. 473). 


\section{THE SITUATION AT HAND}

A business faculty member at Southeastern Louisiana University developed and implemented that school's first public relations class. That class teaches the basics of public relations and incorporates the basics of crisis management into the course. The course included multiple realistic scenarios that students have to respond to in the form of a crisis response plan and statement. The statement is presented to a "press conference" of students and the professor. Students are expected to be familiar with each case and address the concerns the crisis presents. The "press corps" of classmates and the professor questions the crisis managers as to their statements, reported actions and plans to bring the crisis to an end.

A variety of original cases have been used. Each case is developed by the faculty member and distributed to students. Cases have changed over the years but have dealt with a variety of situations including plant explosions and fires, politicians who have been accused of extra-marital sexual trysts, crime in the streets, and accidental shootings. The cases and all firms/individuals mentioned were (and are) fiction. However, students are expected to research the situation described and plan to deal with the crisis. A "press kit" including a written press release explaining the situation and the official response is expected. The press conference is the culmination of the case.

\section{EXAMPLE CASE - THE SHOT HEARD ROUND THE QUARTER (FICTION)}

\section{Background}

You are the public information officer for the New Orleans Police Department. New Orleans, the second largest city in Louisiana is located on the Mississippi River. Though it has been five years since the flooding which followed Hurricane Katrina, much of the city is still in recovery mode. Tourism is down. Business is down. City finance coffers, artificially inflated for two years due to federal funds that poured in to help the city deal with the rebuilding, are beginning to concern many as they appear to be falling at a faster rate than they are being replenished with tax inflows. Indeed, the high tax/fee rate on hotel rooms in the city, arguably among the higher in the country, are still failing to supply the city with the levels of needed tax monies to support and grow the services provided to the citizens.

Crime, a problem before the flooding, has been exacerbated by large numbers of out of state gang members who see the situation as a haven for their activities. Abandoned properties are serving as production facilities for drugs and havens for other illegal activities. The surge in the number of transients in the city hampers normal police investigations. Inadequate protection for witnesses to crime, and less than stellar conviction rates are fueling an already scary situation. Indeed, the historical rate of conviction for violent crime in New Orleans - seven percent is low by any comparison. A large immigrant population that came seeking opportunities for work, and who often cannot speak English, is proving to be prime targets for criminals since immigrants often do not have easy access to banks and as a result, often carry cash.

In addition, for a variety of reasons, including the firing of many officers, the number of police officers needed in New Orleans has not kept pace with the city's needs. National Guard and state police officers helped fill the gap. However, State Police patrols are returning to normal and the Guard has phased out its presence in the city.

As a group, the police are dedicated to their jobs and to their city. They work long hours in a city in which the criminal element seems to be growing. Police salaries are relatively low compared to other, less dangerous jobs and compared to the police of other cities. Still, morale is relatively good at the moment as evidenced by increasing numbers of recruits signing up, and the large number of retirement age officers who elect to continue their employment.

\section{The Incident}

A shooting occurred near the French Quarter yesterday afternoon. Details are sketchy, but the following is in a preliminary report from Police Headquarters to you. 
- $\quad$ Two patrol officers were on patrol on the edge of the Quarter when they came upon an apparent robbery in process.

- $\quad$ The officers had no prior warning and were as much in amazement as were the two alleged robbers.

- The police began pulling their weapons when the robbers began aiming their guns in the direction of the officers.

- Shots were exchanged. By all accounts, it appeared that both of the alleged robbers and the two officers all fired their handguns during the encounter.

- $\quad$ At least 23 shots were fired.

- $\quad$ One of the two suspects died on the scene. The second was transported to a hospital where, after surgery for two wounds, is in critical condition. Upon his release from the hospital, he faces charges including armed robbery, assault, assault on a police officer, and possession of a firearm by a felon.

- $\quad$ Both suspects have lengthy arrest records. The suspect that died was released from Parish Prison only four days earlier. He had been serving three years for armed robbery.

- $\quad$ One of the officers was wounded and after surgery is reported in good condition.

- $\quad$ The alleged victim of the crime was not wounded and though distraught, is in good shape.

- $\quad$ Sadly, during the shooting, a resident was struck by a stray bullet. The individual was sitting in his den watching television when the bullet shattered a window, and struck the homeowner in the chest. The wounded individual is in critical condition following surgery, but is responding to treatment and is expected to have a full recovery.

- The investigation is continuing. Police are not yet sure if the homeowner was shot by a police officer's gun or by one of the alleged robbers. That question will hopefully be addressed in the next day or so. The officers involved were carrying 40 caliber handguns. A .357 magnum revolver and a .45 caliber handgun were recovered from the suspects.

\section{Problems}

Mike Williams, the homeowner who was shot is well known locally. He is a vocal critic of the Police Department and is often quoted in news articles dealing with crime. Understandably, Mr. Williams' family is upset. Mr. Williams' son was on last evening's news alleging the shooting was no accident. Indeed, he all but accused the officers of a cover up and an attack on his father.

Connie Browning, identified as the President of the Royal Benevolent Friends of the Quarter (RBFOQ) was interviewed on the 6:00 Good Morning NOLA show. She reports her organization will sue the Police Department, claiming it is responsible for allowing crime to go unchecked - hurting the Quarter's business and living environments. Her statement also claimed indifference by the Police was hurting property values as well. Browning claimed the high crime rate was concocted so politically connected people will be able to buy up the Quarter for pennies on the dollar. She said such indifference is criminal, that she and her organization will not take it any longer, and will file suit against the City on behalf of the RBFOQ.

Finally, numerous homeowners and irate citizens have called for a march on City Hall to register their displeasure. There is talk of a sit-in demonstration to bring the City government to a halt - until something is done about crime in the city. The march may occur next Monday morning.

\section{The Press Conference}

You have called a press conference for 10:30 a.m. to explain the situation, the Police Department's actions, and to provide information that will allay people's concerns. You will explain what is being done to address the problem and what can be expected as a result of those actions. You will make a formal statement on behalf of the Police Department, and then answer questions of the reporters who will be present in large numbers.

It is $10: 30$ 


\section{TEACHING NOTES AND SUGGESTIONS}

Students and the professor serve as reporters with questions. Since all students are familiar with the case (albeit fictional), all are expected to question the presenter. Press conferences are videotaped for later review. Students are expected to look and speak the part of the official spokesperson.

The professor uses an assessment form to evaluate each presentation. The form includes a numerical rating of 1-10 on various aspects of the presentation. Items assessed during the presentation include dress, eye contact, clarity of voice and diction, knowledge of the case, sincerity and apparent concern for the public safety, and truthfulness.

Later, the press release and kit are evaluated for completeness. The release must conform to expectations of all releases as discussed in class. Correct spelling and grammar are expected. Information must be accurate. The kit should contain the release, news items of interest, and documentation of efforts the city is undertaking to fight crime.

Finally, the "reporters" in class are evaluated. Since they are expected to ask insightful questions, those that do receive points for their participation. There is an expectation all students will participate and learn from this experience.

Note: Individuals and organizations, and the specifics of the case are fictional.

\section{AUTHOR INFORMATION}

Connie B. Budden's research interests include international management, crisis management education and leadership. She is a management faculty member at Southeastern.

Michael C. Budden is the Mayfield Professor of Marketing at Southeastern. His research interests include business education, marketing and public relations, ethics and commercial law.

\section{REFERENCES}

1. Arens, W. F. (2006). Contemporary Advertising, 10 $0^{\text {th }}$. McGraw Hill, Boston, MA: p. 343-344.

2. Arens, W. F. and Schaefer, D. H. (2007). Essentials of Contemporary Advertising. McGraw Hill, Boston, MA: p. 464.

3. Hill, C. W. L. (2011). International Business: Competing in the global marketplace, $8^{\text {th }}$. McGraw Hill / Irwin. New York, NY.

4. Lamb, C. W., Hair, J. F. and McDaniel, C. (2011). Marketing, 11 $1^{\text {th }}$ Thomson / Southwestern, Mason, OH: pp. 581-582.

5. Lussier, R. N. and Achua, C. F. (2007). Leadership: Theory, Application, Skill Development, $3^{\text {rd }}$. Thomson / Southwestern. Mason, OH: p. 473.

6. Seitel, F. P. (2007). The Practice of Public Relations, $10^{\text {th }}$. Pearson / Prentice-Hall. Upper Saddle River, NJ: pp. 405-406. 